Article

\title{
Experimental and Numerical Analyses of the Failure of Prestressed Concrete Railway Sleepers
}

\author{
Ramon Silva *(D), Welington V. Silva, Jonas Yamashita de Farias, Marcos Aires A. Santos and \\ Leonardo O. Neiva \\ Department of Civil and Environmental Engineering, SG-12 Building, Darcy Ribeiro Campus, University of \\ Brasilia, Brasilia 70910-900, Brazil; welington.vital@gmail.com (W.V.S.); jonasyamashita@hotmail.com (J.Y.d.F.); \\ marcosairess@gmail.com (M.A.A.S.); leonardo.ferrovias@gmail.com (L.O.N.) \\ * Correspondence: ramon.silva@unb.br
}

Received: 13 March 2020; Accepted: 30 March 2020; Published: 5 April 2020

check for updates

\begin{abstract}
This paper carries out the assessment of load-carrying capacity of prestressed concrete sleepers, in accordance with Brazilian Standard (ABNT NBR 11709) and AREMA Standard. In a lot of railways around the world, many prestressed concrete sleepers have failed due to Rail Seat Abrasion (RSA) and corrosion. RSA is the wear degradation underneath the rail on the surface of prestressed concrete sleepers. In this paper, a numerical study was carried out to evaluate the load-carrying capacity of the prestressed concrete sleepers, using ABAQUS software. The nonlinear using Concrete Damage Plasticity model was validated by 18 experimental results, in accordance to standards. Using the validated model, the influence of different wear depth RSA, combined with corrosion of the prestressed wires, is investigated.
\end{abstract}

Keywords: prestressed concrete sleeper; rail seat; corrosion; railway engineering; finite element analysis

\section{Introduction}

The sleeper is one of the fundamental elements of the superstructure of the railway tracks. In summary, its main functions are to support the rails, keep the axis of the track constant and transmit to the ballast the actions of the axles of the vehicles. These functions make it necessary to provide the sleeper with a high level of strength, which in general leads to great stiffness; at the same time, it is also necessary to have a certain level of elasticity, since it must be able to withstand extremely high impact forces [1-3]. In the early twentieth century, the first reinforced concrete sleepers imitated, in their design, the shape of wooden sleepers, consisting of a concrete block with a constant section. The results were not satisfactory, as the shocks and vibrations arising from the dynamic actions of the vehicles quickly caused cracks in the upper and central part of the sleeper; despite the steel bar placed to withstand tensile forces, they were not effective in preventing the collapse of the sleeper. Steel bars with stirrups were used to avoid shear cracks; however, it was not very efficient, due to the difficulty of manufacturing the sleeper, and cracks in the concrete contributed to corrosion of steel bars [3-7].

In order to overcome this deficiency, with a bigger nominal concrete cover, to avoid corrosion of the reinforcement concrete, it was applied in concrete the corrosion inhibitors. Corrosion inhibitors are useful in cases where it is not possible to achieve full concrete cover on the reinforcement; however, they raise the price of the sleeper [8-11].

Thus, with the development of prestressed concrete, the possibility arose to combat cracks in concrete, giving rise to a new stage in the design of concrete sleepers. Prestressed concrete sleepers used in railways emerged historically from World War II, and recently there was an increase in their use due to their technical superiority, in order to replace wooden sleepers [11]. 
The purpose of the prestressed force on the rebars is that the stress applied to the steel wires allows the material to remain compressed, even under bending, thus avoiding the opening of tensile cracks. Recently, the need for sleepers' replacement in old railroads has been increasing, as well as the average increase of the speed guide provided by increasingly modern trains, which economically justifies the large amount of studies on this theme around the world $[5,12,13]$.

The sleepers are subjected to cyclic loads during their whole life; the materials that comprise them are subjected to an intense process of fatigue. It is desirable that the sleeper is free of cracks under dynamic loading, because if cracks occur, there is a great increase in stresses in the prestressing reinforcement and an increase of up to $50 \%$ in the transfer length [14-16]. Therefore, designing a prestressed sleeper is a good solution to avoid problems with simple concrete $[1,15,17,18]$.

Thus, this paper aims to evaluate the mechanical behavior of prestressed concrete sleepers, in accordance with the Brazilian and American standards and the common pathologies they are submitted to over their design life. A comparison is made between the results obtained numerically by the software ABAQUS and the experimental curves obtained through the tests, as recommended by ABNT NBR 11709 [19] and AREMA [20]. Eighteen experimental tests in sleepers were carried out, in order to validate the nonlinear numerical model, using ABAQUS [18]. In addition, using the validated numerical model, the influence of the combined effect of rail seat abrasion and corrosion in the load-carrying capacity of the sleepers was evaluated [4,10,21-23].

\section{Experimental Investigations}

\subsection{Details of Prestressed Sleeper}

Eighteen sleepers were taken from the Brazilian railway and were tested in in the Infrastructure Laboratory-INFRALAB and in the Structures Laboratory-LABEST of the University of Brasilia, using the Brazilian Standard (ABNT NBR, 11709) [19].

The sleepers were designed for a positive moment of 2856 and $1786 \mathrm{kN} . \mathrm{cm}$ for the negative moment in the center of the sleeper. An initial prestressing force of $51 \mathrm{kN}$ was applied to the $13 \phi 6.3$ $\mathrm{mm}$ wires. Figure 1 shows the geometric dimensions of the sleeper specimens.

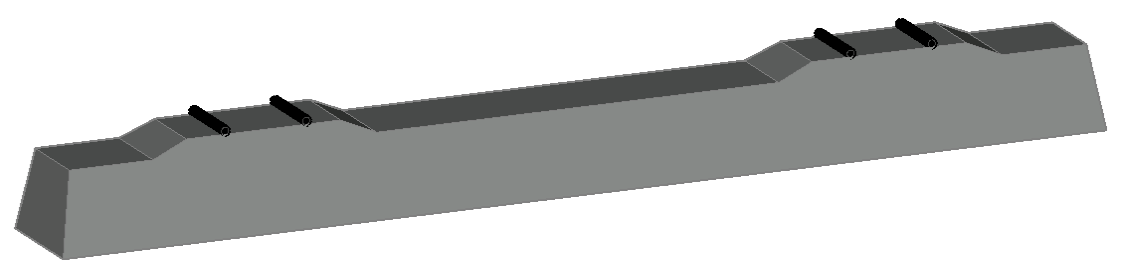

(a)

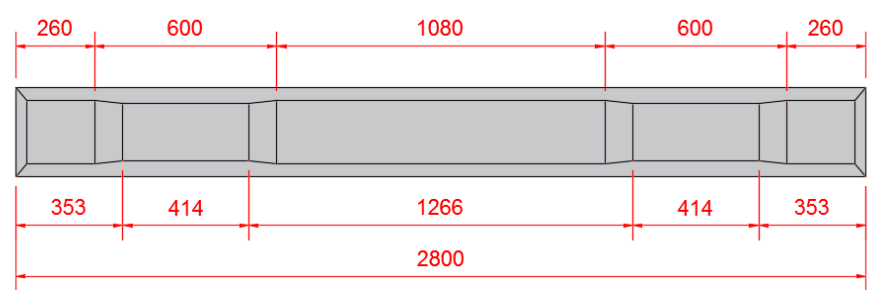

(b)

Figure 1. Cont. 


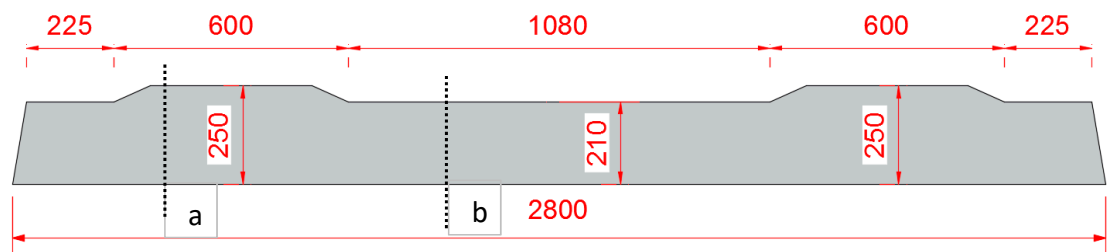

(c)
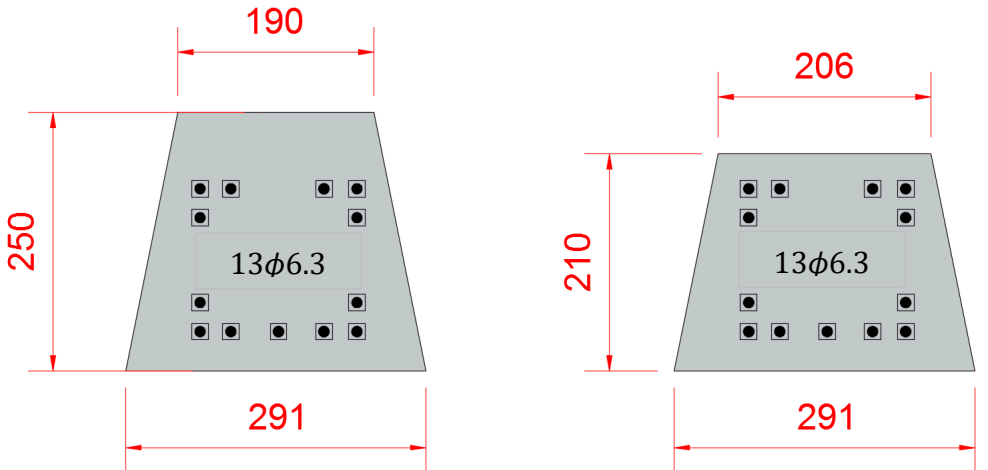

(d)

Figure 1. Detail of the geometry of the sleepers; (a) 3D view of the sleeper; (b) plan view; (c) side view; and (d) cross-section of the prestressed concrete sleeper.

\subsection{Compressive Strength Test of Concrete and Experimental Procedures}

For the concrete compressive strength test, two specimens were extracted from five sleepers of the same batch, using a drill bit with a water-cooled diamond drill, which was capable of extracting specimens with a diameter of $68 \mathrm{~mm}$ and a height of up to $200 \mathrm{~mm}$ (see Figure 2).

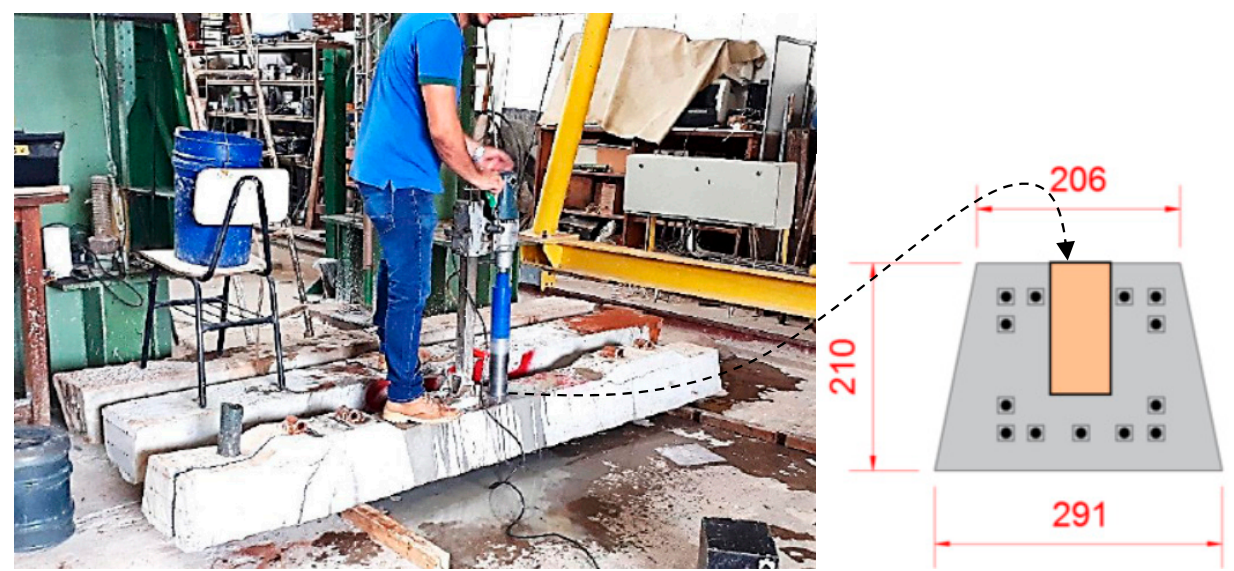

Figure 2. Execution of specimen extraction for concrete testing.

After the extraction of the specimens, the surfaces at the end of the specimens were leveled with the aid of a grinding machine with a diamond disc, and then the compression test was carried out by using the procedure of the Brazilian standard ABNT NBR 5739 [24]; the results are shown in Table 1. After obtaining the results of the compressive strengths $(f c)$, the analysis corrections indicated by Item 6.2 of the Brazilian standard ABNT NBR 7680 [25] were performed by using coefficients of correction $k_{1}, k_{2}, k_{3}$ and $\mathrm{k}_{4}$, given by the following equation:

$$
f_{c i, e x t}=\left[1+\left(k_{1}+k_{2}+k_{3}+k_{4}\right)\right] \cdot f_{c i, e x t, \text { initial }}
$$


where $k_{1}$ represents a correction for the relationship between the height of the specimen $(h)$ and the diameter $(d) ; k_{2}$ would be the correction of the boring effect according to the diameter of the specimen; $k_{3}$ is the direction of extraction in relation to the casting of the concrete, considered equal to zero because it was adopted that the direction of the concreting was parallel to the casting of the concrete; and $k_{4}$ is the effect of moisture in the core; for structures without contact with water, this value is equal to 0.04 , so it was possible to obtain the strengths of the concrete and the modulus of elasticity.

Table 1. Results of the concrete extraction and compression test.

\begin{tabular}{ccccccccccc}
\hline $\begin{array}{c}\text { Sleeper } \\
\text { Specimen }\end{array}$ & $\begin{array}{c}\boldsymbol{d} \\
(\mathbf{m m})\end{array}$ & $\begin{array}{c}\boldsymbol{h} \\
(\mathbf{m m})\end{array}$ & $\begin{array}{c}\boldsymbol{h} / \boldsymbol{d} \\
(-)\end{array}$ & $\begin{array}{c}\boldsymbol{k}_{\mathbf{1}} \\
(-)\end{array}$ & $\begin{array}{c}\boldsymbol{k}_{2} \\
\mathbf{( - )}\end{array}$ & $\begin{array}{c}\boldsymbol{k}_{3} \\
(-)\end{array}$ & $\begin{array}{c}\boldsymbol{k}_{4} \\
(-)\end{array}$ & $\begin{array}{c}\text { Area } \\
\left(\mathbf{m m}^{2}\right)\end{array}$ & $\begin{array}{c}\text { Load } \\
(\mathbf{k N})\end{array}$ & $\begin{array}{c}\text { Stress } \\
(\mathbf{M P a})\end{array}$ \\
\hline CP1 & 68 & 121.1 & 1.78 & 0.01 & 0.12 & 0 & 0.04 & 3631.7 & 79.4 & 85.0 \\
CP2 & 68 & 121.0 & 1.78 & 0.01 & 0.12 & 0 & 0.04 & 3631.7 & 64.6 & 69.1 \\
CP3 & 68 & 132.4 & 1.95 & 0.01 & 0.12 & 0 & 0.04 & 3631.7 & 57.7 & 61.7 \\
CP4 & 68 & 132.9 & 1.96 & 0.01 & 0.12 & 0 & 0.04 & 3631.7 & 58.1 & 62.1 \\
CP5 & 68 & 120.6 & 1.77 & 0.01 & 0.12 & 0 & 0.04 & 3631.7 & 49.2 & 52.6 \\
CP6 & 68 & 110.7 & 1.63 & 0.02 & 0.12 & 0 & 0.04 & 3631.7 & 59.3 & 62.9 \\
CP7 & 68 & 132.4 & 1.95 & 0.01 & 0.12 & 0 & 0.04 & 3631.7 & 57.7 & 61.7 \\
CP8 & 68 & 132.9 & 1.96 & 0.01 & 0.12 & 0 & 0.04 & 3631.7 & 58.1 & 62.1 \\
CP9 & 68 & 120.6 & 1.77 & 0.01 & 0.12 & 0 & 0.04 & 3631.7 & 49.2 & 52.6 \\
CP10 & 68 & 110.7 & 1.63 & 0.02 & 0.12 & 0 & 0.04 & 3631.7 & 59.3 & 62.9 \\
\hline
\end{tabular}

Although the concrete strength adopted in the design is $50 \mathrm{MPa}$, it was found that condition of the concrete in the test age of about 1 year obtained an average strength of $63.67 \mathrm{MPa}$. The prestressing tendons are the chevron-patterned indented wires with ultimate strength of prestressed steel $1750 \mathrm{MPa}$. From visual inspection, it could be observed that the high-strength prestressing wires were of high quality, and thus the strength would not change so fast during the time. For carry out the experimental tests, the loading $P_{j}$ was applied at a speed of less than $50 \mathrm{kN} / \mathrm{min}$, until the appearance of the first bending crack. Such moment generated with the first crack simulates the field conditions. Subsequently, a load was applied at a rate of $60 \mathrm{kN} / \mathrm{min}$, until the sleeper failure. Figure 3 shows the details of the experimental test.

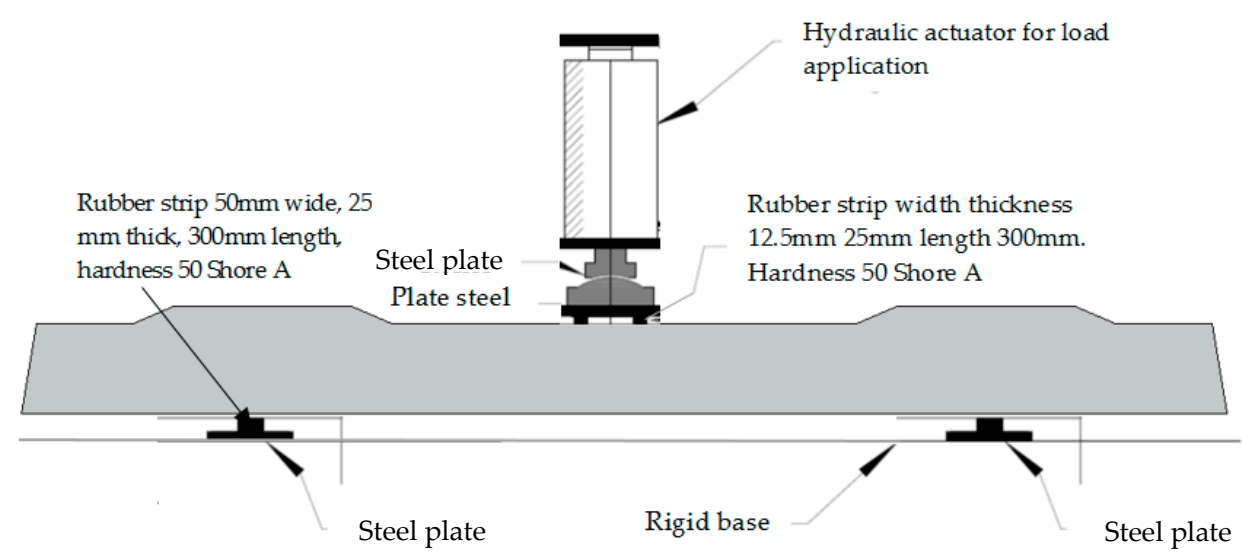

(a)

Figure 3. Cont. 


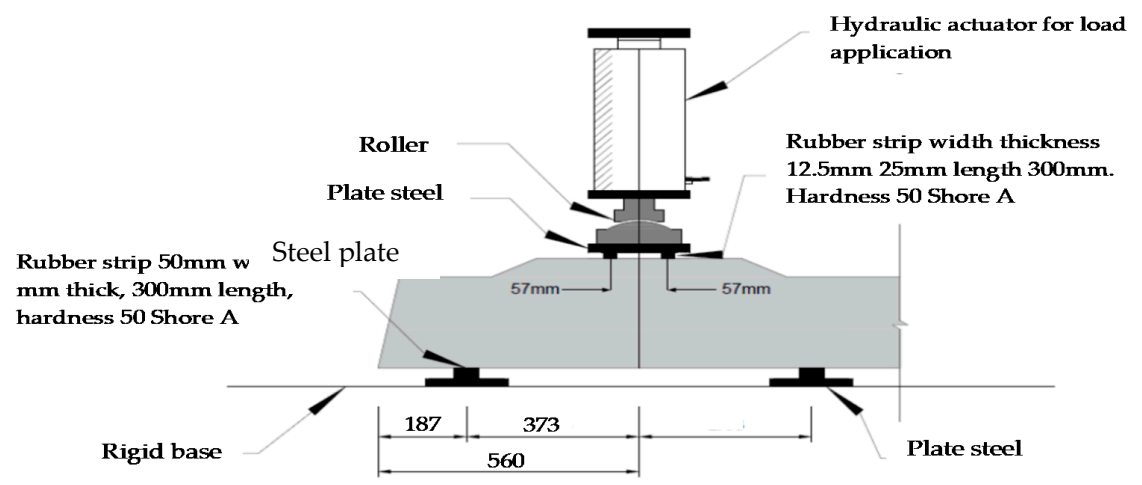

(b)

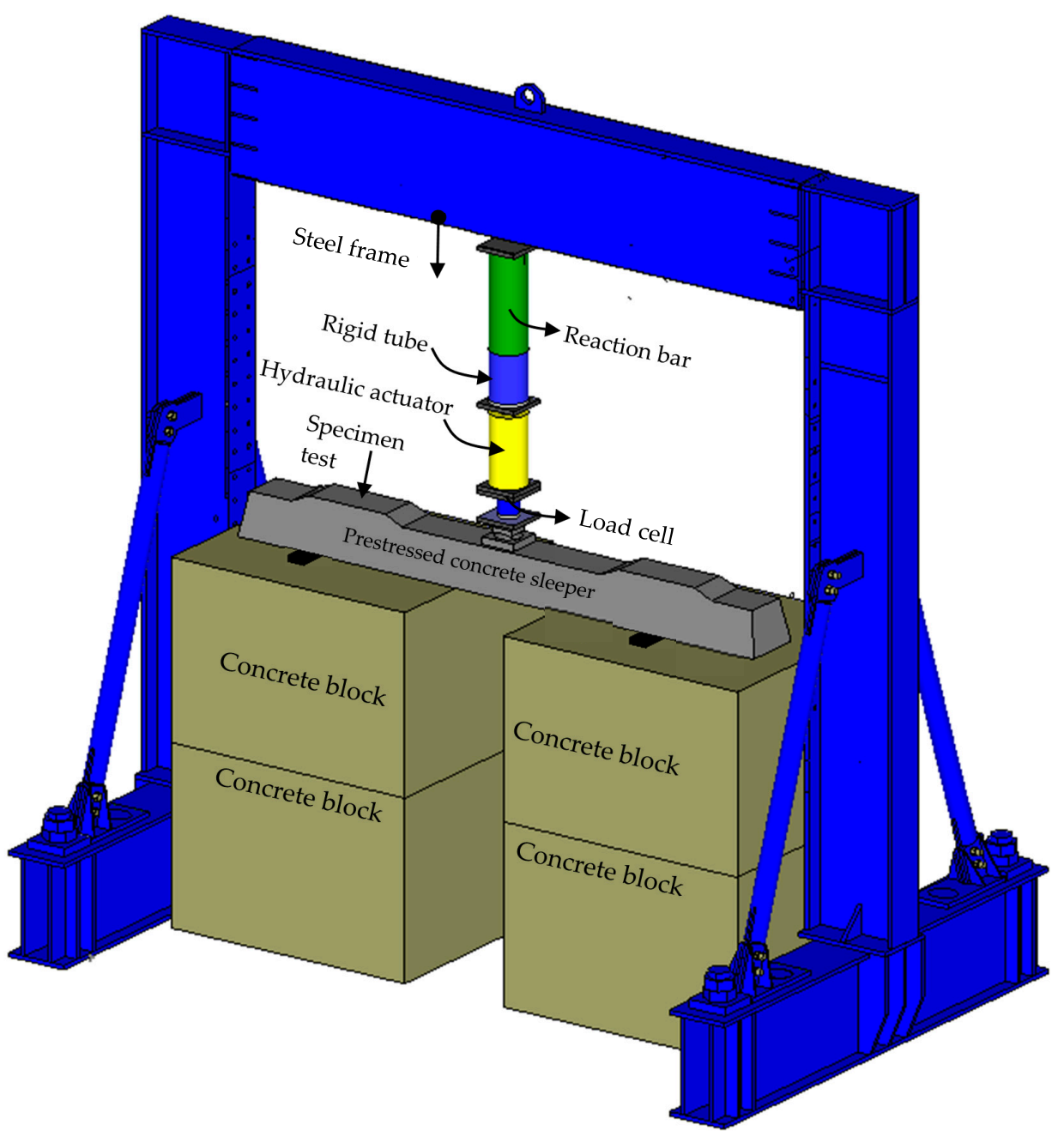

(c)

Figure 3. Cont. 


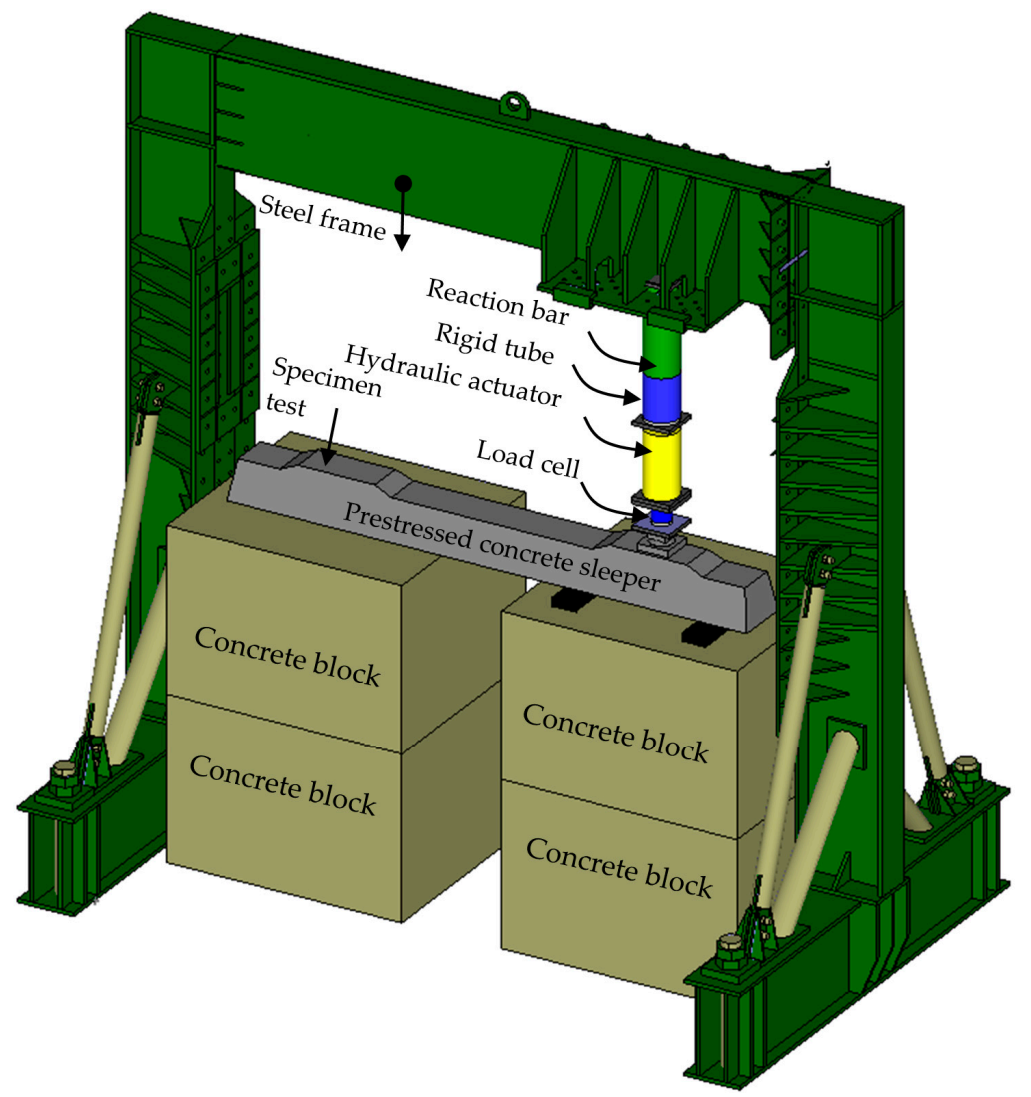

(d)

Figure 3. Experimental tests: (a) detail of positive moment test at midspan; (b) detail of positive moment test at the support; (c) positive moment test at midspan-schematic model in INFRALAB Laboratory; and (d) positive moment test at the support-schematic model in Structures Laboratory-LABEST.

Two test systems were developed; in the first test, eight sleepers were subjected to a positive moment test with load application at midspan of the sleeper supported on concrete blocks in the reaction frame. In the second, the load was applied on the base plate, which is attached to the rail of the railway, with ten experimental tests. In adherence tests, LVDT (Linear Variable Differential Transformer) was used to obtain the displacements at the load application point, and also in the prestressing wires at the end of the sleeper. Figure 4 shows details of the LVDT's installed next to the prestressing wires in the sleeper.
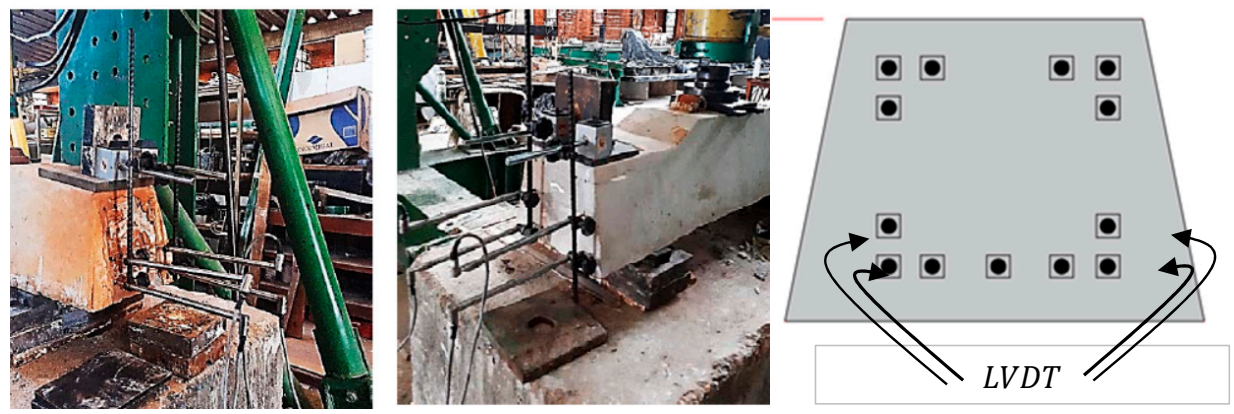

Figure 4. Position of wires tested with LVDT (Linear Variable Differential Transformer) to obtain the wire displacements, experimental test in Structures Laboratory. 
For the simple bending test, this paper shows the details of the experimental tests by using one LVDT to measure the displacement in the center of the sleeper. The load was applied and controlled with a system set consisting of a three-phase motor responsible for pumping the hydraulic oil, a key that controlled the pressure outlet and a hydraulic actuator with a capacity of $1000 \mathrm{kN}$ coupled in a load cell of $1500 \mathrm{kN}$. The reading was automatic by means of a system that recorded the data at a rate of $2 \mathrm{H}_{\mathrm{Z}}$. Subsequently, the results were plotted for comparison with a numerical model.

\section{Experimental Results and Discussion}

The sleepers with one year of use were removed from the railroad for testing. Ten sleepers were chosen to test the resistance in the rail support. In the load test of positive moment at the support, shown in Figure 4, an increasing load with a rate of $50 \mathrm{kN} / \mathrm{min}$ was applied, until reaching the total load of $278 \mathrm{kN}$, and kept for $8 \mathrm{~min}$. The average slips of both the lower and the second layer threads were plotted in Figure 5. It can be seen that, during those $8 \mathrm{~min}$, the wire displacements were less than $0.025 \mathrm{~mm}$, in accordance with the allowed limit by the standard ABNT NBR 11709 (2015) [19]. Therefore, there is still good adherence between the concrete and the wires. After this, the load was increased until the sleeper failure. Table 2 shows the summary of the results of these tests.
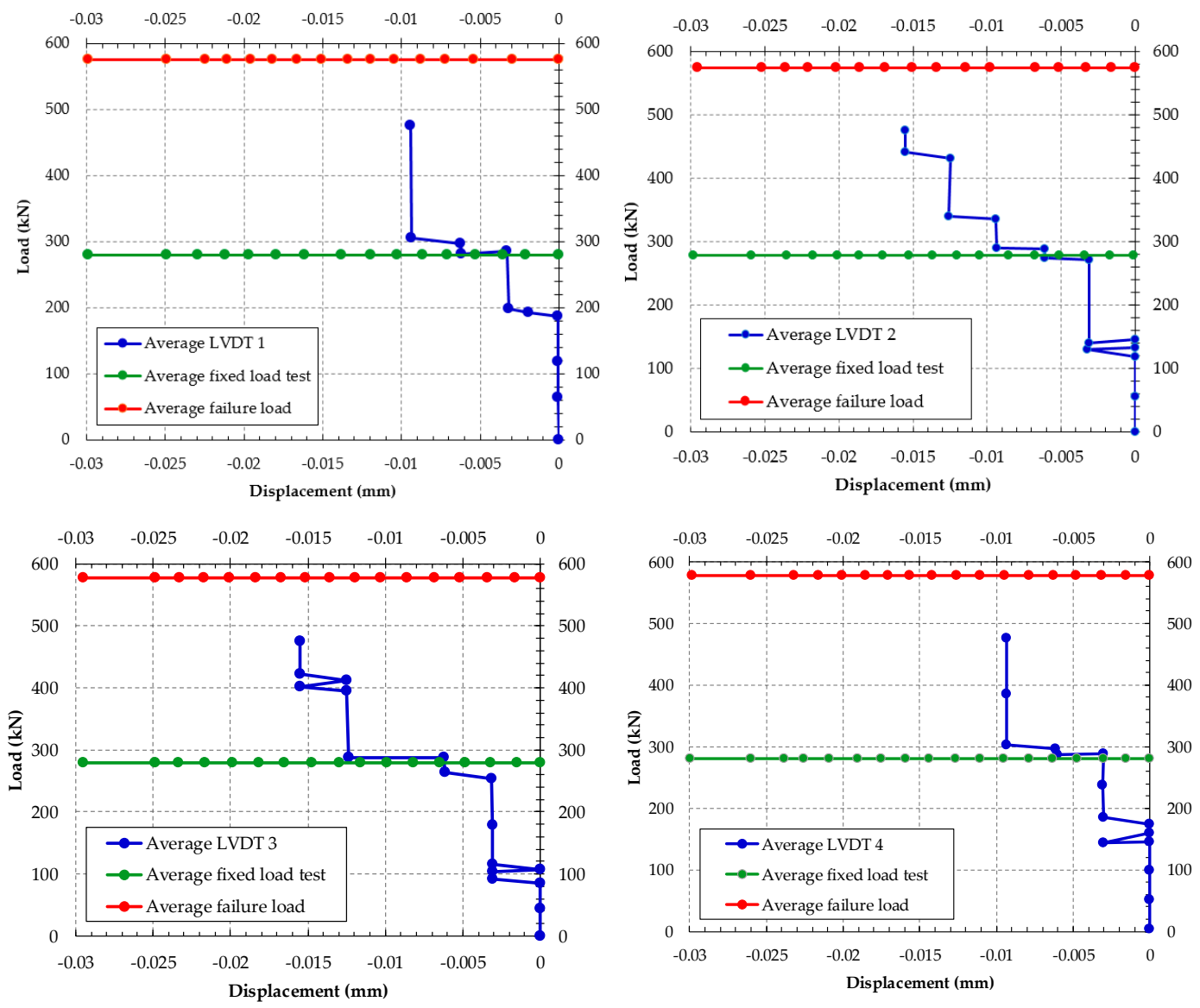

Figure 5. Average failure load of the sleepers tested with load on the support. 
Table 2. Summary of positive moment at the support.

\begin{tabular}{cccccc}
\hline $\begin{array}{c}\text { Sleeper } \\
\text { Specimen }\end{array}$ & $\begin{array}{c}\text { Reference } \\
\text { Load (kN) }\end{array}$ & $\begin{array}{c}\text { Average Load } \\
\text { Applied (kN) }\end{array}$ & $\begin{array}{c}\text { Load Time } \\
\text { Applied (min) }\end{array}$ & $\begin{array}{c}\text { Crack Load of the } \\
\text { Sleeper (kN) }\end{array}$ & $\begin{array}{c}\text { Failure Load } \\
(\mathbf{k N )}\end{array}$ \\
\hline SS1 & 278.24 & 278.24 & 8 & 267.60 & 576 \\
SS2 & 278.24 & 278.31 & 8 & 233.10 & 566 \\
SS3 & 278.24 & 278.02 & 8 & 210.50 & 490 \\
SS4 & 278.24 & 278.21 & 8 & 262.20 & 578 \\
SS5 & 278.24 & 278.22 & 8 & 254.4 & 601 \\
SS6 & 278.24 & 278.24 & 8 & 248.1 & 608 \\
SS7 & 278.24 & 278.27 & 8 & 234.41 & 589 \\
SS8 & 278.24 & 278.18 & 8 & 241.17 & 589 \\
SS9 & 278.24 & 278.31 & 8 & 238.11 & 583 \\
SS10 & 278.24 & 278.26 & 8 & 238.10 & 597 \\
\hline
\end{tabular}

Figure 6 presents the main modes of rupture of the sleepers, with the load on the base plate of the rail.

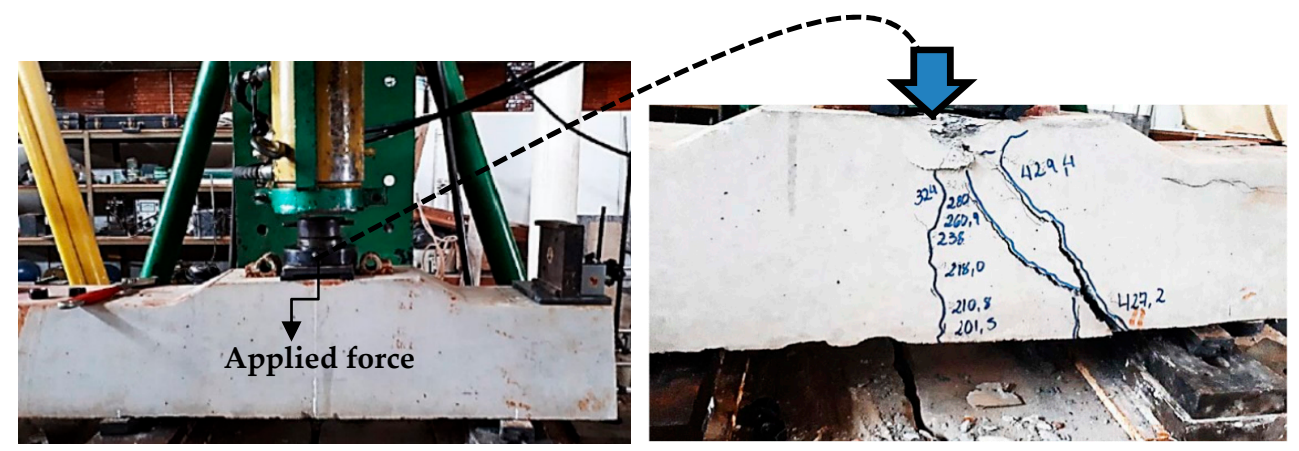

(a)
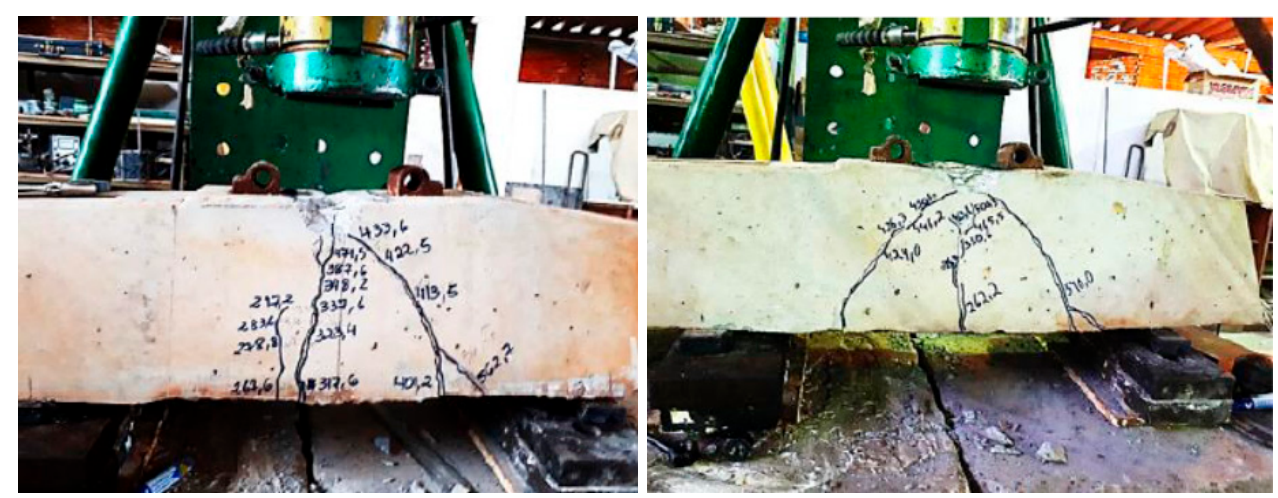

(b)

Figure 6. The main failure mode of the sleepers in the positive moment at support: (a) failure of the sleepers tested in the Structures Laboratory; and (b) failure by shear combined with flexion.

In the positive moment test at the midspan with increasing load, the tensile failure stress was reached in the midsection, and the first vertical cracks with an average load of $278 \mathrm{kN}$ appeared, covering half the height of the sleeper, or up to one just below the neutral line. In this phase, the tension forces were absorbed by the prestressed wires. After the beginning of this stage, the extreme sections of the concrete have not yet reached the breaking stress, but with the progressive increase in the load, the concrete began to have inclined cracks, until the failure of the lower wires.

At this stage, the concrete showed crushing in the upper fibers, and the failure occurred with the increase of bending and shear cracks (see Figure 7). Figure 8 shows the load vs. displacement curves of the experimental tests. 


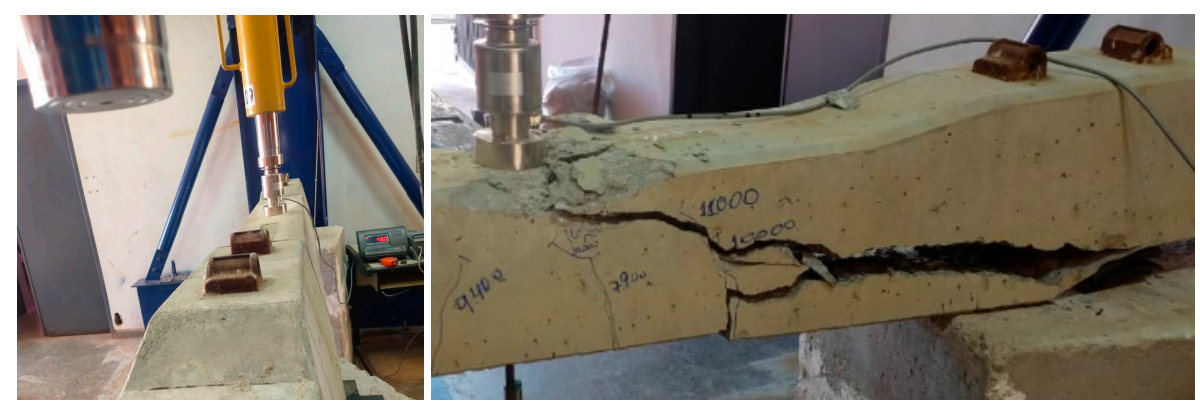

(a)
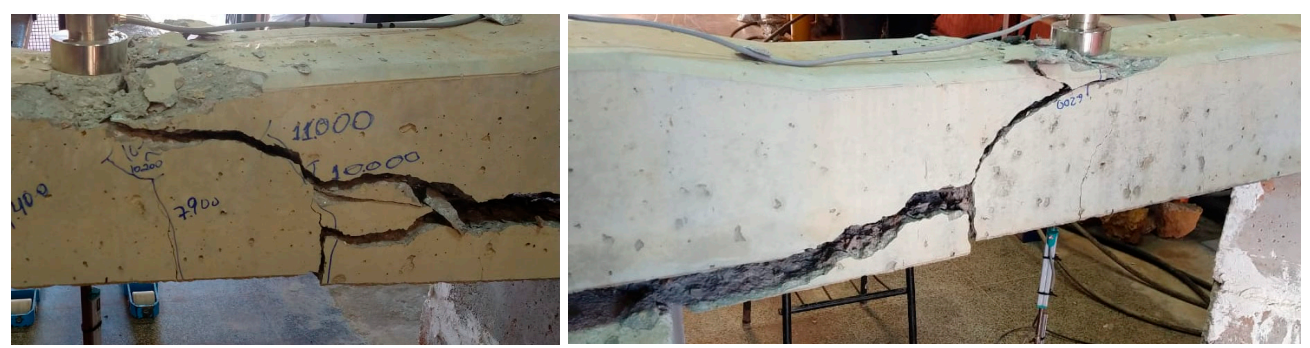

(b)
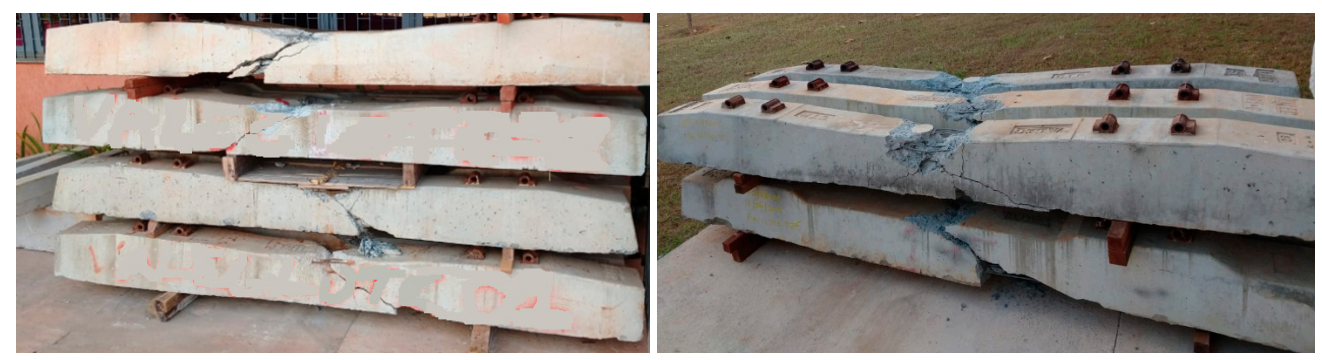

(c)

Figure 7. (a) Failure by simple bending; (b) failure in the positive moment test at the midspan; and (c) specimens tested in the INFRALAB Laboratory.

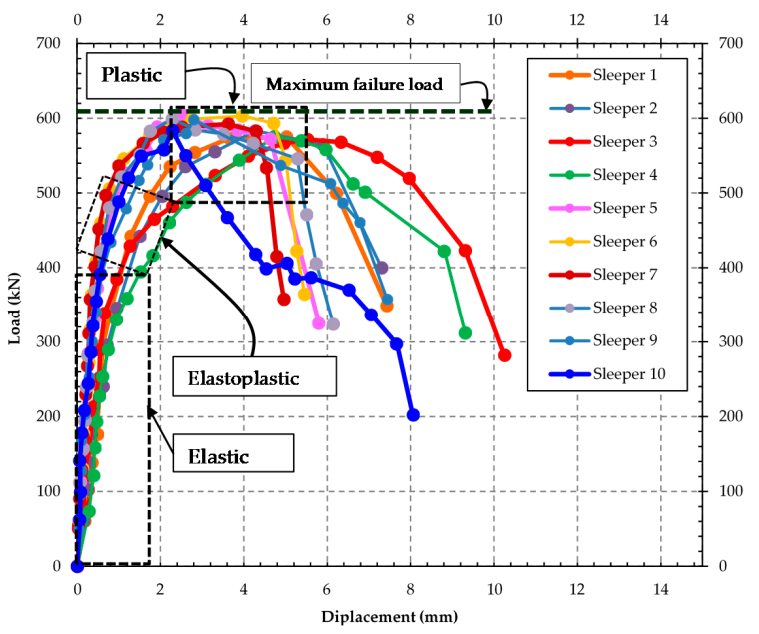

(a)

Figure 8. Cont. 


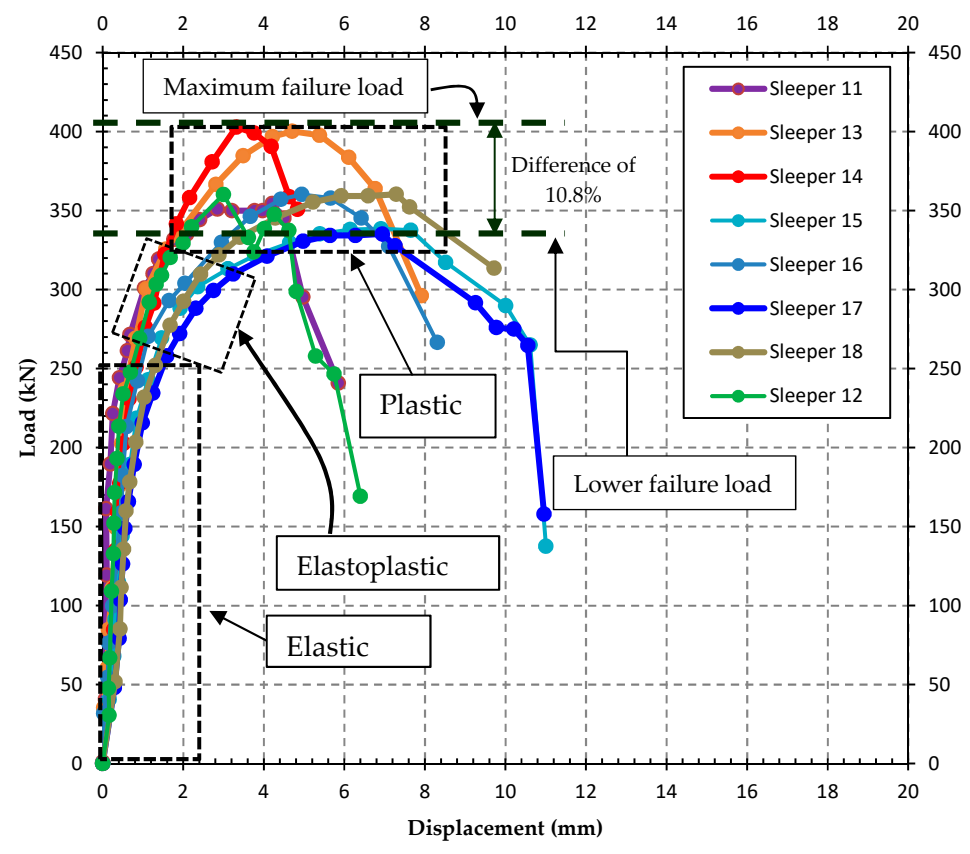

(b)

Figure 8. Experimental results: (a) positive moment test at midspan; (b) positive moment test at the support.

As shown in Figure 8, the elastic stretch corresponds to loads of 400 and $250 \mathrm{kN}$, respectively. In this initial phase of the tests, the bending-moment values observed were not very high in the cross-section of the sleeper. The normal stresses at each point in the section had linear variation with the distance from the neutral line in the tension zone. Such zone stresses were lower than the tension strength of the concrete, already in the compressed zone, did not reach the compressive strength of concrete. Nevertheless, with the increase in the load values in the two tests with values of 500 and $350 \mathrm{kN}$ (Figure 8a,b), the first cracks appeared, and the sleeper passed to have an elastoplastic stretch, and the concrete reached plastification in the tension zone; in other words, there is no linear response and the gradual increase of displacement.

In the first test, when the loads reached $566 \mathrm{kN}$, there was a total of plastification of the sleeper section with yielding of steel wire and concrete failure by crush of the compressed section. In the simple bending test, the plastic load that causes the failure of the sleeper was between 350 and $400 \mathrm{kN}$. At this stage of the test, the loss in tension strength of the concrete, the tension stresses were not completely resisted by steel wires, and consequently, it yields. Therefore, the failure range of the sleeper had a difference of $10.80 \%$ (Figure $8 \mathrm{~b}$ ). In all tests, it was evidenced the total use of the sleeper section with the equilibrium between the vectoral components of tension and compression.

\section{Finite Element Analysis}

\subsection{Numerical Model of the Concrete Sleeper}

In the concrete crack model, it is assumed that cracking is the most important factor in the material's behavior. A "completely non-isotropic" behavior will govern the material after it has cracked. However, cracks influence the process of the computations and create problems for convergence of the results.

Using the concrete crack model is advisable in cases where the concrete is under relatively low stresses (almost one-fourth or one-fifth of the pressure which could be tolerated by the concrete).

Therefore, in this study, we used the Concrete Damage Plasticity (CDP) model, with ABAQUS [26]. The Concrete Damage Plasticity model uses the concept of isotropic damage in the linear region and 
combines the isotropic tensile strength and plasticity pressure, to show the nonlinear behavior of the concrete [27].The model introduced in this paper for the damaged concrete is a continuous model based with plastic behavior and the cracks caused by stresses are the main damage mechanism in the model [28].

Damaged plasticity is assumed to characterize the uniaxial tensile and compressive response of concrete, as shown in Figure 9. At the beginning, the stress-strain relationship is linearly elastic under uniaxial tension, until the value of the failure stress, $\mathrm{ft}_{0}$, is reached. Failure stresses in concrete block are converted to replace microcracks in it. Beyond the state of the failure stress in concrete, stress-strain response is designed by softening characteristics (Figure 9a).

Under uniaxial compression, the response is linear until the value of initial yield, $f_{c 0}$. After attaining the ultimate stress, $f_{c u}$, in the plastic zone, the response of concrete is characterized by the stress hardening, followed by strain softening (Figure 9b) [12].

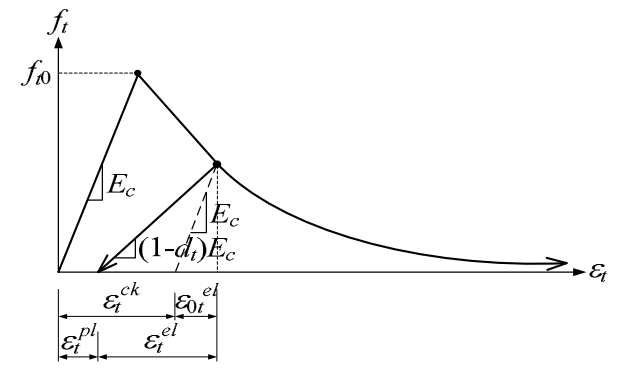

(a)

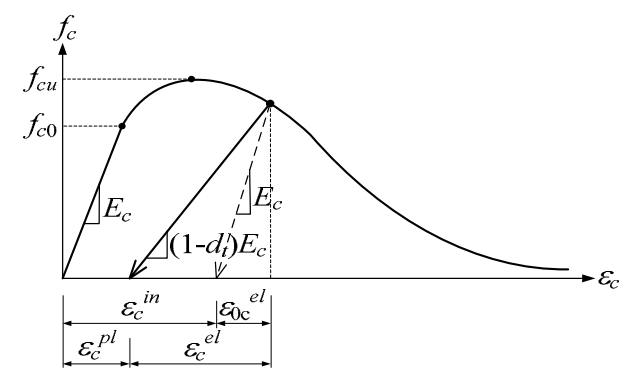

(b)

Figure 9. Concrete Damage Plasticity model: (a) tension behavior associated with tension stiffening; and (b) compressive behavior associated with compression hardening.

Therefore, concrete stresses determined unloading from any point on the strain are given by the following equations:

$$
\begin{aligned}
& f_{t}=E_{c}\left(\varepsilon_{t}-\varepsilon_{t}^{p l}\right)\left(1-d_{t}\right) \\
& f_{c}=E_{c}\left(\varepsilon_{c}-\varepsilon_{c}^{p l}\right)\left(1-d_{c}\right)
\end{aligned}
$$

where $E_{c}$ is the modulus of elasticity of concrete. Then, the effective tensile and compressive cohesion stresses of concrete are estimated as follows:

$$
\begin{gathered}
\bar{f}_{t}=\frac{f_{t}}{\left(1-d_{t}\right)}=E_{c}\left(\varepsilon_{t}-\varepsilon_{t}^{p l}\right) \\
f_{c}=E_{c}\left(\varepsilon_{c}-\varepsilon_{c}^{p l}\right)\left(1-d_{c}\right)
\end{gathered}
$$

which determine the size of the failure surface. The post-failure behavior of reinforced concrete represents by means of the post-failure stress as a function of cracking strain $\varepsilon_{t}{ }^{c k}$ and $\varepsilon_{c}{ }^{c k}$, which are defined as the total strain minus the elastic strain corresponding to the undamaged material, and tension stiffening data are given in terms of the cracking strains [27]. The implantation of the damage method with the plastic deformation was inserted in the ABAQUS program, where the user adds the data of the material properties obtained in experimental tests. ABAQUS automatically calculates the graph of the strain, using the low equations ABAQUS [29]:

$$
\begin{aligned}
& \varepsilon_{t}^{p l}=\varepsilon_{t}^{c k}-\frac{d_{t}}{\left(1-d_{t}\right)} \frac{f_{t}}{E_{0}} \\
& \varepsilon_{c}^{p l}=\varepsilon_{c}^{c k}-\frac{d_{c}}{\left(1-d_{c}\right)} \frac{f_{c}}{E_{0}}
\end{aligned}
$$


where $\varepsilon_{t}{ }^{c k}$ represents the plastic tensile strains of the concrete, and $\varepsilon_{c}{ }^{c k}$ represents the plastic compression strains of the concrete. Property values for the assumed constitutive model of concrete and steel discussed above were collected from the specimens' test results carried out in the INFRALAB Laboratory and the Structures Laboratory at the University of Brasilia.

\subsection{Material Models}

In the FEM analysis, the Young's modulus of concrete was adopted as $E_{0}=38 \mathrm{GPa}$, and the Poisson ratio as $v=0.17$. By using Equations (4) to (7), it was possible for us to obtain the curves shown in Figure 10, which shows the parameters defining the nonlinear behavior of concrete, in both the tension and compression zones [30]. The physical laws of concrete were described by using the function proposed by [31].
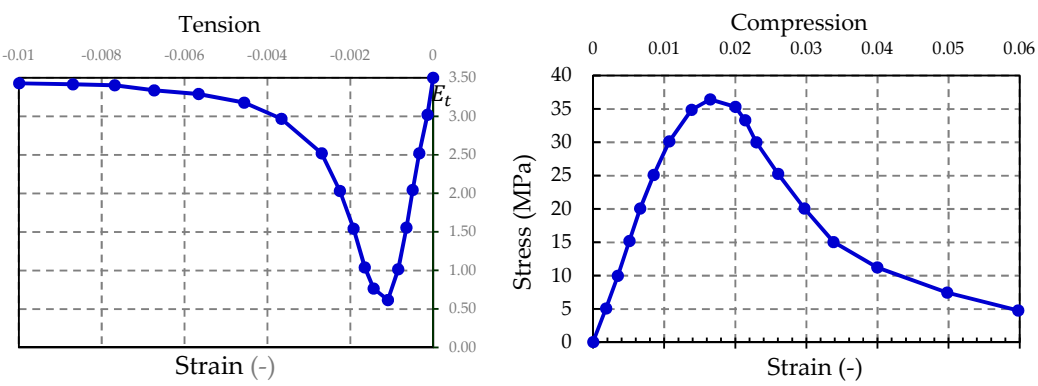

Figure 10. Physical laws of the concrete modeled in the numerical calculations.

This model includes combinations of non-associated plasticity with hardening and scalar isotropic elastic damage, to determine irreversible changes that occurred during the loading and unloading cycles. The CDP model is based on the brittle-plastic degradation model created by Lubliner et al. [32,33] and later perfected by Alfarah, López-Almansa and Oller [31] which assumes that the two main mechanisms of destruction are cracking as a result of stretching and crushing of the concrete under compression. In Table 3 presents the dimensionless properties of the concrete, using as input file in ABAQUS [34].

Table 3. Parameters of the Concrete Damage Plasticity model.

\begin{tabular}{ccccc}
\hline $\begin{array}{c}\text { Internal Friction } \\
\text { Angle } \\
\boldsymbol{\beta}\end{array}$ & $\begin{array}{c}\text { Eccentricity of the } \\
\text { Plastic Potential } \\
\epsilon\end{array}$ & $f \mathrm{~b} 0 / f \mathrm{c} 0$ & $\begin{array}{c}\text { Shape of the Plastic } \\
\text { Potential Surface } \\
\text { Kc }\end{array}$ & $\begin{array}{c}\text { Viscosity Parameter } \\
\boldsymbol{\mu}\end{array}$ \\
\hline $36^{\circ}$ & 0.1 & 1.16 & 0.667 & 0.005 \\
\hline
\end{tabular}

The concrete, in turn, was described by using the Abaqus Concrete Damage Plasticity model (Table 3), which is used for comprehensive modeling of concrete in a complex stress state [35-42].

The Concrete Damage Plasticity (CDP) model was used in the modeling of concrete, present in the ABAQUS material library and also the parameters in Lubliner et al. [32,33] and [42]. This constitutive model is suitable for materials that have different resistance to tension and compression; besides, it links the theory of plasticity with the mechanics of damage, being able to numerically simulate the degradation of the stiffness and failure of the concrete. The failure mechanisms considered are based on tension cracking and compression crushing. The CPM assumes a non-associative plastic flow rule, where the Drucker-Prager hyperbolic function is applied to define the potential flow. In this study, an elastic-plastic constitutive model was used to simulate prestressing steel.

This constitutive model is present in the ABAQUS material library, under the name PLASTIC. The PLASTIC model adopts the flow criterion of Von Mises, with an associative flow rule, ideal for the modeling of ductile materials such as steel. 
The uniaxial behavior implemented in the model consisted of the bi-linear stress-strain [30,33]. Table 4 shows the details adopted for steel. The elastic-plastic material model was adopted for the constituent elements of the sleeper. Based on the yield criterion, the material was subject to the plastic flow rule and kinematic hardening rule (see Figure 11). Hardening was determined by adopting a tangent Young's modulus of $E_{t}=0.01 E$.

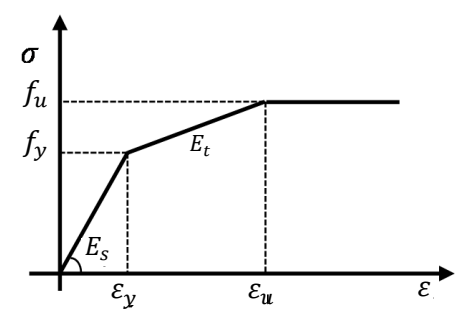

Figure 11. Stress-strain relationship for steel material.

Table 4. Material properties of steel in the numerical model.

\begin{tabular}{|c|c|c|c|c|}
\hline $\begin{array}{c}\text { Elastic Modulus, } \\
E_{s}(\mathrm{MPa})\end{array}$ & $\begin{array}{c}\text { Hardening } \\
\text { Modulus } E_{t}(\mathrm{MPa})\end{array}$ & $\begin{array}{c}\text { Yield Stress, } f_{y} \\
(\mathrm{MPa})\end{array}$ & $\begin{array}{c}\text { Poison Coefficient, } \\
v(-)\end{array}$ & Density $\left(\mathrm{kN} / \mathrm{m}^{3}\right)$ \\
\hline $205.000 \mathrm{MPa}$ & $200 \mathrm{MPa}$ & $1700 \mathrm{MPa}$ & 0.3 & 78 \\
\hline
\end{tabular}

The explicit dynamic analysis used in this paper was a strategy due to the greater possibility of numerical convergence, based on the nonlinear analysis method with time control. Despite being a dynamic analysis, this method is capable of performing quasi-static analyses, provided that small increments of loads are applied, so that the low effect of inertia prevails. It is very efficient in the analysis of complex numerical models that involve material damage, large deformations and contact interactions between components.

\subsection{Loading Application and Boundary Conditions}

The loading points for external loads were selected for the standard one-point beam-bending configuration, in such a way that the bending moment was combined with shear (see Figure 12). In the numerical computations, the concentrated load was applied perpendicularly to the loaded surface, through many points, considering a perfect rigid body.

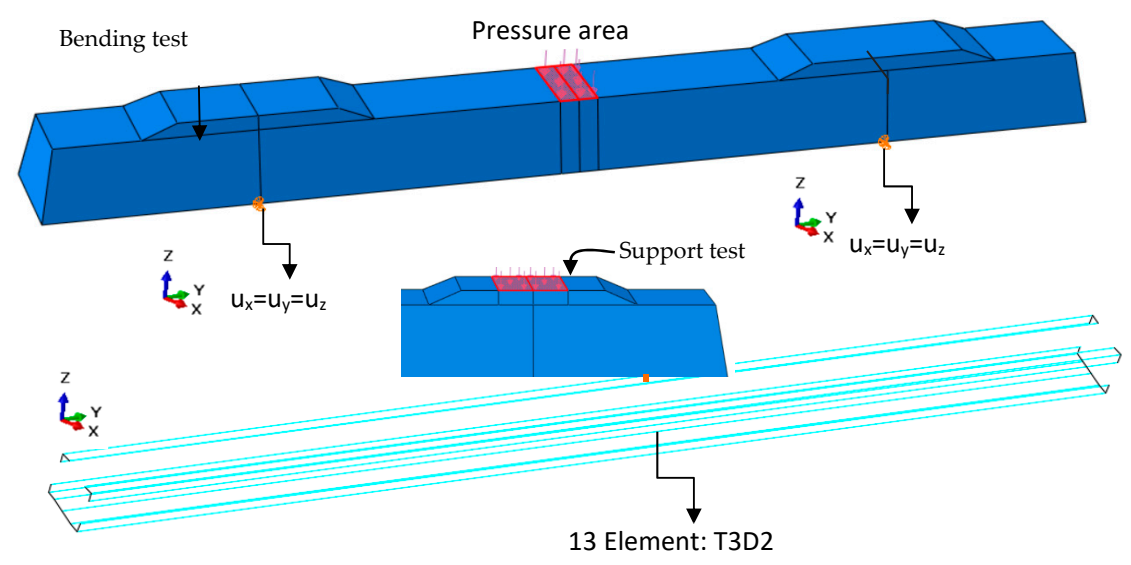

Figure 12. Cont. 


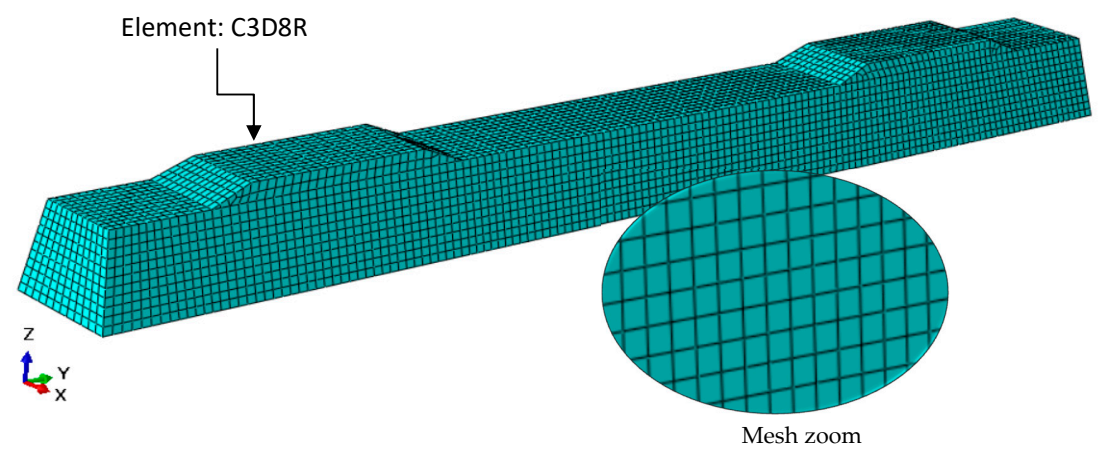

Figure 12. Boundary conditions adopted in the numerical model.

\subsection{Validation of Numerical Models}

The models were carried out by using eight-node reduced-integration solid elements (C3D8R-concrete sleeper) and two-node linear truss elements (T3D2-prestressed wires in concrete). Both were modeled discretely as elements embedded in the concrete of the sleeper. In all computations were considered both the physical nonlinearity of the materials and the geometric nonlinearity resulting from high deformation. The numerical models were verified based on the list of calculated displacements, ultimate loads and failure modes of the investigated sleepers and numerical model. For the simulation, we used the Riks [43] method, implemented in ABAQUS [25], with arc length and geometric nonlinearity [44].

The deflection used was in the vertical plane of the cross-section, at the middle of the span on the external part of the sleeper $\left(U_{z}\right)$. The highest displacements determined in the numerical analysis $\left(U_{z}, F E\right)$ were similar to the results of laboratory tests $\left(U_{z}, E x p\right)$. The largest difference between the numerical and experimental deflections) was $5 \%$ (see Figure 13).

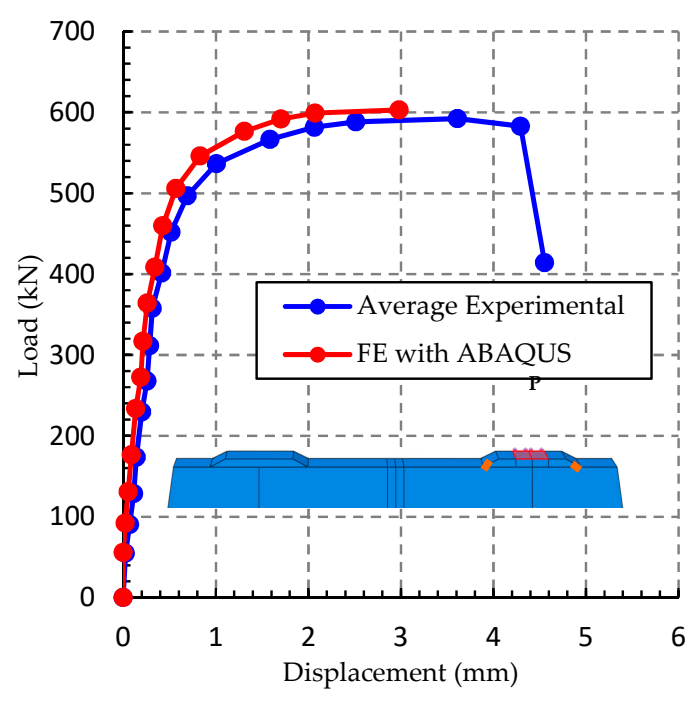

(a)

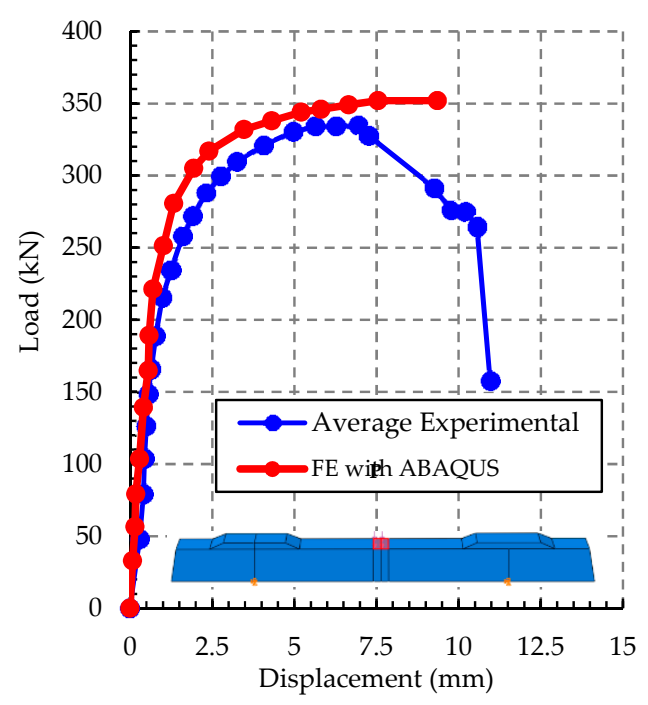

(b)

Figure 13. Comparison of vertical displacements $\left(U_{z}\right)$, determined through experimental tests and numerical analysis: (a) load at sleeper support; and (b) load at midspan.

For the extreme sections, under simple bending of the sleeper, the idealized model is similar to a truss, which considers the interaction between the bending moment and the shear force. In this model, the truss has longitudinal, compressed and tensioned flanges, as in the midsection, connected by top compression web (compressed concrete) and bottom chord. 
The compressed diagonals, called connecting rods, represent the concrete between the cracks. The bottom chord of the truss represents the prestressing wires. Figure 14 shows the failure modes of the sleepers.

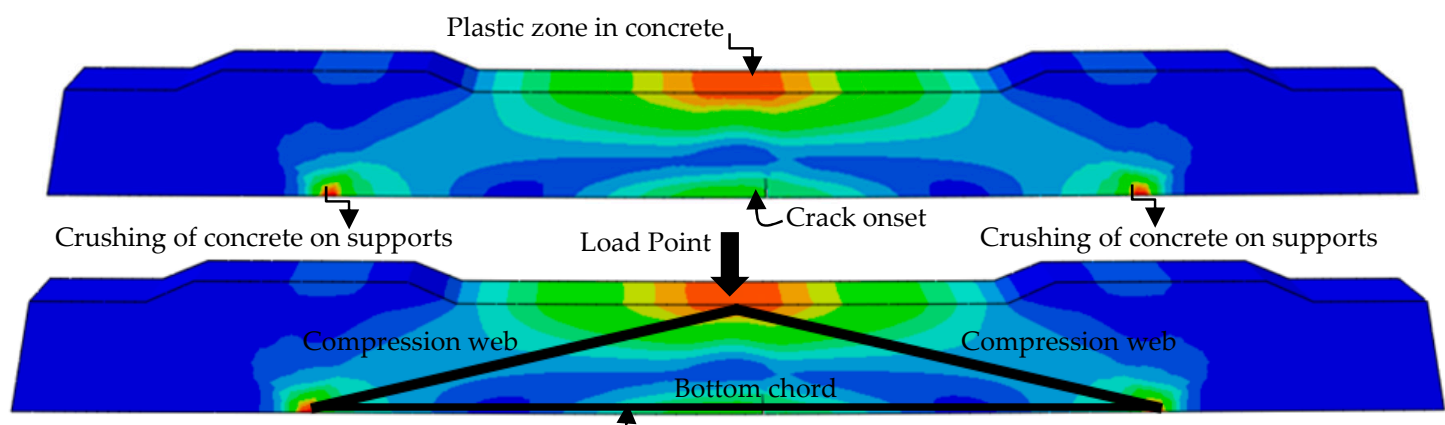

Concrete with typical truss model

(a)

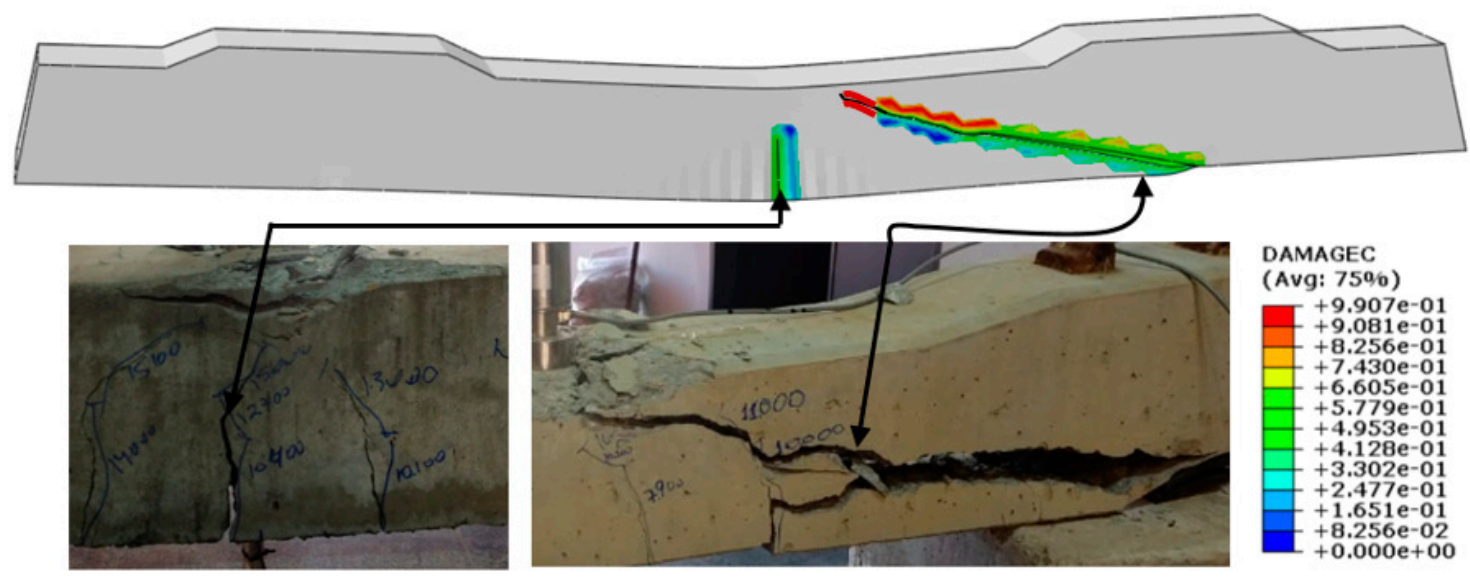

(b)

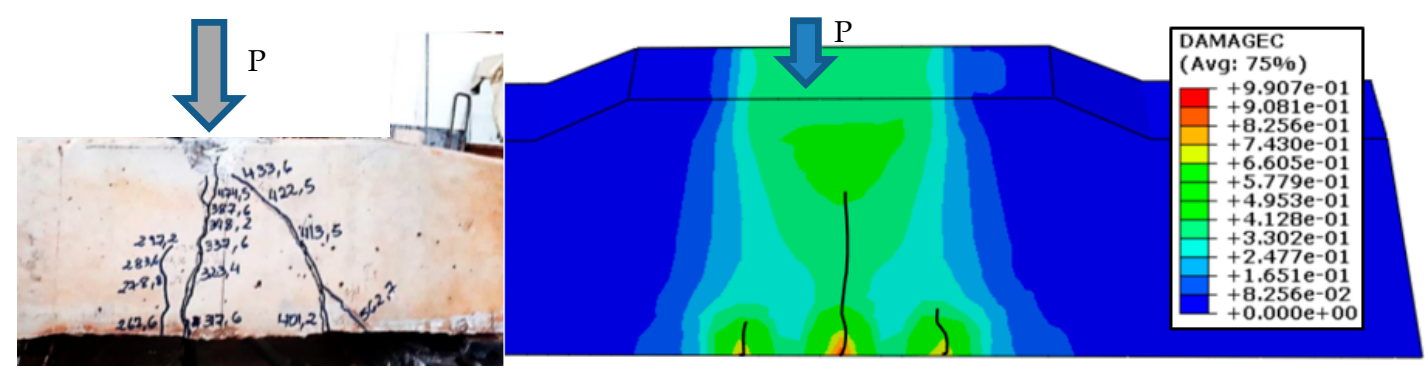

(c)

Figure 14. Comparison of failure modes: (a) idealization of the sleeper failure model to the plane truss; (b) comparison of failure modes of the bent sleeper; and (c) comparison of sleeper failure modes, with load applied at the support.

\section{Pathologies Simulation}

The first recurring problem that can result in structural failure in sleepers, especially in heavy-rail prestressed sleepers, is the failure by Rail Seat Abrasion (RSA). This deterioration is the result of an abrasion process, which is a gradual wear of the concrete cement paste, exposing the aggregate of the sleeper surface below rail foot $[13,36,37]$. RSA is related to weather, traffic and layout conditions. The wear of the concrete is due to the shear stress between the rail seat and the rail pad. Factors such as axle load, traffic volume, grid line curvature and inclination, presence of fines, water, and freeze-and-thaw cycles contribute to the wear of this region. Additionally, over the past two decades, durability and 
longevity of concrete structures have also been the focus of many researches. Amongst the main causes that lead to lifetime reduction is cracking due corrosion of the reinforcement wires prestressed.

In order to analyze the RSA, the concrete abrasion of the sleeper was simulated in the ABAQUS program. Four damage cases of abrasion by reduction of depth $(d)$ were applied $(10,20,30$ and $60 \mathrm{~mm})$. The location and dimension of abrasion are shown in Figure 15, and reduction depth was simulated. This parametric study on ABAQUS consisted of decreasing the length of the entire wire along the length of the sleeper, to simplify the model. If the reduction of the diameter of the wire was located in a part of its length, the model would be very complex. It will require modeling the wires with Shell element, consequently, with the use of different types of nonlinear contacts; thus, the model was simplified.

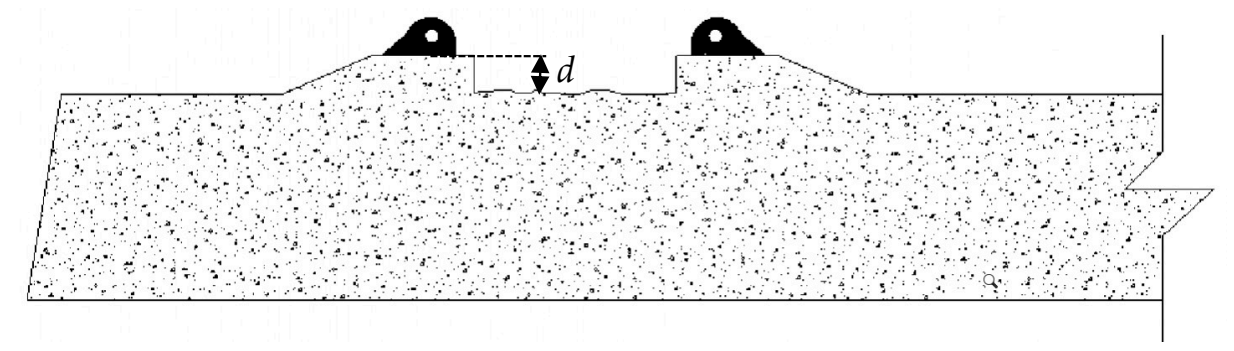

Figure 15. Detail of the Rail Seat Abrasion.

In order to simulate the pathology in the numerical model, we performed a reduction in the diameter of the protection wires. It was observed in practice that, on railway lines, sleepers in use suffer cracks next to the supports. The depth was obtained by inspection; the maximum crack value was $60 \mathrm{~mm}$. Figure 16 shows details of a cracked sleeper. The value of the decrease in wire diameter was based on the literature [15-17].

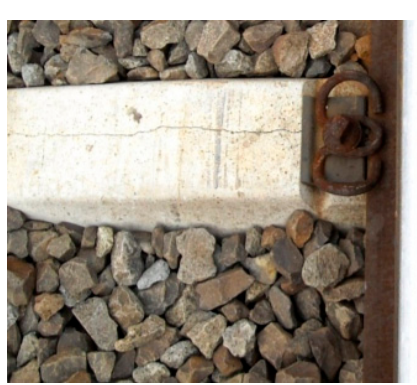

(a)

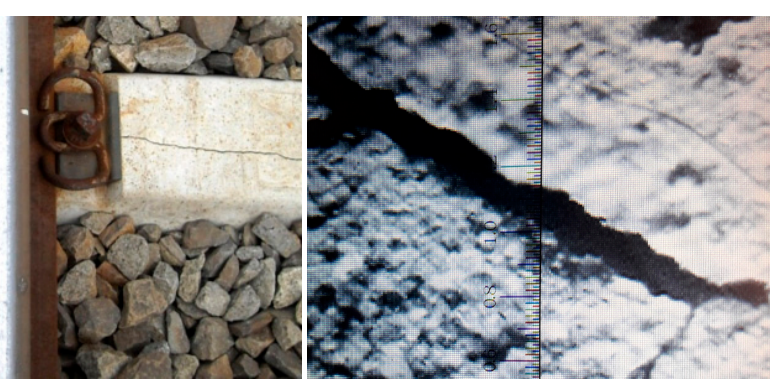

(b)

Figure 16. Detail of the cracked sleeper on the Brazilian railway: (a) sleeper with crack in the support; and (b) crack detail with laser fissurometer.

In order to simulate the corrosion of the bars, four damage cases were applied by diameter reduction of the lower bars $(1,2,3$ and $6 \mathrm{~mm})$, for failure with numerical simulation of the sleeper in ABAQUS [32]. The element T3D2 was used in the model for the prestressed wires, considering their adhesion with concrete made by the embedded region iteration that considers the bars perfectly anchored in the concrete. The combined effects of RSA and corrosion were simulated in ABAQUS. The load-deflection responses for the sleepers are shown in Figure 17. Observe that the increase of the abrasion depth reduces the stiffness of the sleeper. 


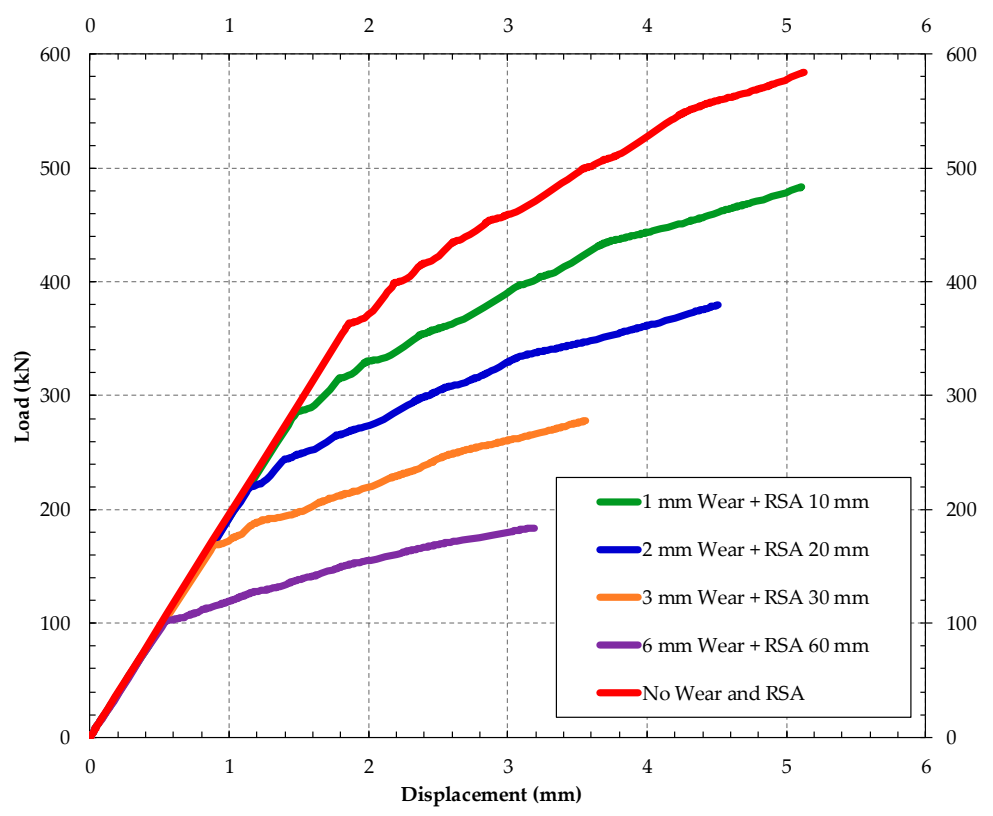

Figure 17. Failure modes for different lengths of pathologies in concrete of the sleeper.

A decrease in the load capacity was expected, since the bending strength is provided mainly due to the active reinforcement located in the tension regions of the concrete; this fact is observed in the Figure 14. With a degradation of $1 \mathrm{~mm}$ in the diameter of the lower reinforcement and RSA of $10 \mathrm{~mm}$, it was possible to notice a $16.52 \%$ reduction in the force to initiate the plastic behavior of the section (from 587 to $490 \mathrm{kN}$ ); for a degradation of $2 \mathrm{~mm}$ diameter and RSA of $20 \mathrm{~mm}$, the active reinforcement had a reduction of $33.56 \%(390.28 \mathrm{kN})$; for $3 \mathrm{~mm}$ and RSA of $30 \mathrm{~mm}$, a reduction of $49.53 \%(290.78 \mathrm{kN})$, while a total corrosion and RSA of $60 \mathrm{~mm}$, and a reduction of the load capacity in a $68.92 \%(182.42 \mathrm{kN})$.

\section{Conclusions}

This paper presents the experimental results of positive moment tests of prestressing sleepers and numerical results of finite analysis to investigate the static behavior of the sleepers. Based on the results, the following conclusions can be drawn in this paper:

- The experimental results pointed out that the sleepers were designed in accordance with Brazilian standards.

- The use of the CDP model for concrete behavior was considered satisfactory. The numerical mechanical behavior was similar to experimental ones from the beginning of plastification up to the final failure stage.

- Simulations of the post-buckling behavior of the structure (in post-critical states) were carried out, using the Riks analysis available in the Abaqus software [26], which enables "passing" through the bifurcation point. In this way, it was possible not only increase but also decrease the force in order to meet the static equilibrium criterion.

- The size of the calculation step in the modified Riks method [43] depends on the "Arc Length", measured along the static equilibrium path in the load-displacement space.

- It was also possible to evaluate the impact of local pathologies in the sleeper's load-carrying capacity. These deleterious effects of reinforcement degradation are responsible for reducing the sleeper strength, which may lead to a loss of more than $50 \%$ of the load-carrying capacity.

- It is important to highlight the relevance of prestressing, good construction practices (well-performed cure and low water/cement ratio) and other anti-cracking mechanisms in the durability of the sleeper in order to get a good response from the sleepers over their service life. 
- The numerical model carried out could be used to predict static responses of prestressed concrete sleepers.

Author Contributions: Conceptualization, R.S.; methodology, R.S., J.Y.d.F. and W.V.S.; investigation, M.A.A.S. and L.O.N.; visualization, M.A.A.S.; writing—original draft preparation, R.S.J.Y.d.F; writing—review and editing, M.A.A.S. All authors have read and agreed to the published version of the manuscript.

Funding: This study was funded by CAPES (the Brazilian Coordination for the Improvement of Higher Education Personnel) and CNPq (the National Council for Scientific and Technological Development), and we thank them for the financial support for this research.

Acknowledgments: The authors are very thankful to the INFRALAB and Structures Laboratories of the University of Brasilia for all tests done, along this research.

Conflicts of Interest: The authors declare no conflict of interest.

\section{References}

1. Remennikov, A.; Kaewunruen, S. Experimental load rating of aged railway concrete sleepers. Eng. Struct. 2014, 76, 147-162. [CrossRef]

2. Farnam, S.M.; Rezaei, F. Part A- experimental: experimental analysis of crack propagation in pre-stressed concrete sleepers by fracture mechanics. Int. J. Transp. Eng. 2017, 5, 17-29.

3. Farnam, S.; Rezaie, F. Simulation of crack propagation in prestressed concrete sleepers by fracture mechanics. Eng. Fail. Anal. 2019, 96, 109-117. [CrossRef]

4. Kaewunruen, S.; Gamage, E.K.; Remennikov, A. Structural Behaviours of Railway Prestressed Concrete Sleepers (Crossties) With Hole and Web Openings. Procedia Eng. 2016, 161, 1247-1253. [CrossRef]

5. Farnam, S.M.; Rezaei, F. Experimental analysis of fracture and damage mechanics of pre-stressed concrete sleepers B70: part B- analysis. Int. J. Transp. Eng. 2017, 5, 163-177.

6. Karihaloo, B.; Nallathambi, P. Fracture toughness of plain concrete from three-point bend specimens. Mater. Struct. 1989, 22, 185-193. [CrossRef]

7. Zi, G.; Moon, D.Y.; Lee, S.-J.; Jang, S.Y.; Yang, S.C.; Kim, S.-S. Investigation of a concrete railway sleeper failed by ice expansion. Eng. Fail. Anal. 2012, 26, 151-163. [CrossRef]

8. Dugarte, M.; Martinez-Arguelles, G.; Torres, J. Experimental Evaluation of Modified Sulfur Concrete for Achieving Sustainability in Industry Applications. Sustainability 2018, 11, 70. [CrossRef]

9. Smith, P. Design and specification of marine concrete structures. Mar. Concr. Struct. 2016, 65-114. [CrossRef]

10. PKoteš, P.; Strieška, M.; Bahleda, F.; Bujňáková, P. Prediction of RC Bridge Member Resistance Decreasing in Time under Various Conditions in Slovakia. Materials 2020, 13, 1125. [CrossRef]

11. Bastos, P.S.S.; Pinheiro, L.M. Prestressed concrete sleepers reinforced with steel fibers. Cad. Eng. Estruturas. 2007, 9, 117-150.

12. Rezaie, F.; Farnam, S. Fracture mechanics analysis of pre-stressed concrete sleepers via investigating crack initiation length. Eng. Fail. Anal. 2015, 58, 267-280. [CrossRef]

13. Kaewunruen, S. Experimental and Numerical Studies for Evaluating Dynamic Behaviour of Prestressed Concrete Sleepers Subject to Severe Impact Loading. Ph.D Thesis, University of Wollongong, Wollongong, Australia, 2007; p. 412. Available online: http://ro.uow.edu.au/theses/277 (accessed on 3 April 2020).

14. Sadeghi, J. Field Investigation on Dynamics of Railway Track Pre-Stressed Concrete Sleepers. Adv. Struct. Eng. 2010, 13, 139-151. [CrossRef]

15. Sadeghi, J. Experimental evaluation of accuracy of current practices in analysis and design of railway track sleepers. Can. J. Civ. Eng. 2008, 35, 881-893. [CrossRef]

16. Kaewunruen, S.; Remennikov, A.M. Experimental and Numerical Studies of Railway Prestressed Concrete Sleepers under Static and Impact Loads. Civ. Comput. 2007, 3, 25-28. Available online: www.uow.edu.au (accessed on 3 April 2020).

17. Remennikov, A.M.; Kaewunruen, S. Investigation of Vibration Characteristics of Prestressed Concrete Sleepers in Free-free and In-situ Conditions. Aust. Struct. Eng. Conf. 2005, 2005, 11-14. 
18. Kernes, R.G.; A Shurpali, A.; Edwards, J.R.; Dersch, M.; Lange, D.; Barkan, C.P.L. Investigation of the mechanics of rail seat deterioration and methods to improve the abrasion resistance of concrete sleeper rail seats. Proc. Inst. Mech. Eng. Part F J. Rail Rapid Transit 2014, 228, 581-589. [CrossRef]

19. ABNT NBR 11709, Concrete sleepers-Design, materials and components. Brazilian Assoc. Tech. Stand. 2015, 137.

20. AREMA. Concrete Ties. In Evalution Tests for Tie Systems; AREMA: Lanham, MD, USA, 2010; Volume 1, Chapter 30, Part 4.

21. Taherinezhad, J.; Sofi, M.; Mendis, P.A.; Ngo, T. A review of behaviour of Prestressed concrete sleepers, Electron. J. Struct. Eng. 2013, 13, 1-16.

22. You, R.; Goto, K.; Ngamkhanong, C.; Kaewunruen, S. Nonlinear finite element analysis for structural capacity of railway prestressed concrete sleepers with rail seat abrasion. Eng. Fail. Anal. 2019, 95, 47-65. [CrossRef]

23. Remennikov, A.M.; Murray, M.H.; Kaewunruen, S. Conversion of AS1085. 14 for Prestressed Concrete Sleeepers to Limit States Design Format, AusRAIL PLUS. 2007, pp. 1-18. Available online: www.uow.edu.au (accessed on 3 April 2020).

24. ABNT NBR 5739. Concrete-Compression test of cylindrical specimens ABNT NBR 5739. Brazilian Assoc. Tech. Stand. 2018, 71.

25. ABNT NBR 7680. Concrete-Sampling, preparing, testing and result analysis of concrete cores Part 1: Axial compressive strength. Brazilian Assoc. Tech. Stand. 2015, 28.

26. ABAQUS. Theory Manual; Version 6.11; Dassault Systèmes Simulia Corp: Providence, RI, USA, 2011.

27. Chen, Z.; Shin, M.; Wei, S.; Andrawes, B.; A Kuchma, D. Finite element modeling and validation of the fastening systems and concrete sleepers used in North America. Proc. Inst. Mech. Eng. Part F: J. Rail Rapid Transit 2014, 228, 590-602. [CrossRef]

28. Rezaie, F.; Farnam, S.M. Sensitivity analysis of pre-stressed concrete sleepers for longitudinal crack prorogation effective factors. Eng. Fail. Anal. 2016, 66, 385-397. [CrossRef]

29. Inc., A. ABAQUS; Dassault Systèmes Simulia Corp: Josnton, RI, USA, 2016.

30. Śledziewski, K.; Górecki, M. Finite Element Analysis of the Stability of a Sinusoidal Web in Steel and Composite Steel-Concrete Girders. Materials 2020, 13, 1041. [CrossRef]

31. Alfarah, B.; López-Almansa, F.; Oller, S. New methodology for calculating damage variables evolution in Plastic Damage Model for RC structures. Eng. Struct. 2017, 132, 70-86. [CrossRef]

32. Lubliner, J.; Oliver, J.; Oller, S.; Onate, E. A plastic-damage model for concrete. Int. J. Solids Struct. 1989, 25, 299-326. [CrossRef]

33. Oller, S.; Onate, E.; Oliver, J.; Lubliner, J. Finite element nonlinear analysis of concrete structures using a "plastic-damage model". Eng. Fract. Mech. 1990, 35, 219-231. [CrossRef]

34. ABAQUS. User's Manual; Version 6.14-1; Dassault Systèmes Simulia Corp: Providence, RI, USA, 2014.

35. Farias, M.M.; Naylor, D.J. Safety analysis using finite elements. Comput. Geotech. 1998, 22, 165-181. [CrossRef]

36. Zeman, J.C.; Edwards, J.R.; Lange, D.A.; Barkan, C.P.L. Investigation of Potential Concrete Tie Rail Seat Deterioration Mechanisms: Cavitation Erosion and Hydraulic Pressure Cracking. In Proceedings of the Transportation Research Board 89th Annual Meeting, Washington, DC, USA, 10-14 January 2009; pp. 1-13.

37. Jin, Z.; Yuan, L.; Pei, S. Efficient evaluation of bridge deformation for running safety of railway vehicles using simplified models. Adv. Struct. Eng. 2019, 23, 454-467. [CrossRef]

38. Jankowiak, T.; Łodygowski, T. Quasi-Static Failure Criteria for Concrete/Quasi-Statyczne Kryteria Zniszczenia Betonu. Arch. Civ. Eng. 2010, 56, 123-154. [CrossRef]

39. Yu, T.; Teng, J.-G.; Wong, Y.; Dong, S. Finite element modeling of confined concrete-II: Plastic-damage model. Eng. Struct. 2010, 32, 680-691. [CrossRef]

40. Kmiecik, P.; Kaminski, M. Modelling of reinforced concrete structures and composite structures with concrete strength degradation taken into consideration. Arch. Civ. Mech. Eng. 2011, 11, 623-636. [CrossRef]

41. Śledziewski, K. Selection of appropriate concrete model in numerical calculation. ITM Web Conf. 2017, 15, 7012. [CrossRef]

42. Lee, J.; Fenves, G.L. Plastic-Damage Model for Cyclic Loading of Concrete Structures. J. Eng. Mech. 1998, 124, 892-900. [CrossRef] 
43. Riks, E. An incremental approach to the solution of snapping and buckling problems. Int. J. Solids Struct. 1979, 15, 529-551. [CrossRef]

44. Aslani, F.; Jowkarmeimandi, R. Stress-Strain model for concrete under cyclic loading. Mag. Concr. Res. 2012, 64, 673-685. [CrossRef]

(C) 2020 by the authors. Licensee MDPI, Basel, Switzerland. This article is an open access article distributed under the terms and conditions of the Creative Commons Attribution (CC BY) license (http://creativecommons.org/licenses/by/4.0/). 